\title{
冬季澳大利亚东侧海温与长江流域夏季降水的联系及 可能物理机制
}

\author{
周波涛 \\ 国家气候中心, 北京 100081 \\ E-mail: zhoubt@cma.gov.cn
}

2011-01-04 收稿, 2011-03-23 接受

公益性行业(气象)科研专项(GYHY200906018)、国家自然科学基金(40805029)和国家重点基础研究发展计划(2009CB421407, 2010CB950304) 资助

\begin{abstract}
摘要 通过对观测资料的分析, 初步探讨了冬季澳大利亚东侧海温和夏季长江流域降水 的关系及可能物理机制. 研究表明, 澳大利亚东侧冬季海温与我国长江流域夏季降水之 间具有同位相变化关系。当冬季澳大利亚东侧海温变暖时，随后夏季西太平洋副热带高 压和东亚西风急流位置往往偏南, 我国大陆沿岸低层盛行异常的西南风, 有利于长江流 域降水增多, 反之亦然. 冬季澳大利亚东侧海温对后期夏季东亚大气环流的影响通过两 种途径来实现: ( i ) 冬季澳大利亚东侧海温异常信号由于自身的持续性可维持到夏季, 并 通过南北半球遥相关影响东亚夏季大气环流的变化; (ii) 冬季澳大利亚东侧海温偏高时, 同期西南印度洋海温也易于偏高. 在海气相互作用下, 这种异常信号逐渐向东发展, 并造 成夏季海洋大陆附近海温升高. 海洋大陆海温的升高反过来影响对流活动进而导致东亚 夏季大气环流异常.
\end{abstract}

关键词

澳大利亚东侧海温

夏季降水

长江流域

遥相关

物理机制
我国地处东亚季风区, 受东亚夏季风活动的影 响, 我国长江流域经常出现干旱或洪涝灾害, 给国民 经济和人民生命财产造成严重损失. 因此, 开展夏季 重大旱涝过程的成因分析和预测理论研究非常重要. 通过这方面的研究, 可以深人认识长江流域夏季降 水的变化机理, 并为短期气候预测提供科学依据.

近 10 多年来, 气象工作者在影响长江流域夏季 降水的前期信号及变化机理方面作了不少研究. 如, 龚道溢等人 ${ }^{[1,2]}$ 分析了春季北极涛动变化对随后夏季 长江流域降水的影响, 发现春季北极涛动偏强(弱)时, 夏季急流位置偏北(南), 长江流域降水偏少(多), 呈 一种反位相变化关系. 王会军等人 ${ }^{[3,4]}$ 的工作揭示, 春季欧亚中高纬大气环流异常在夏季东亚大气环流 和降水变化中起着重要作用. 另外, 春季青藏高原积
雪也与长江流域夏季降水具有密切联系. 春季青藏 高原积雪增多可通过改变土壤湿度影响东亚夏季大 气环流, 最终导致长江流域降水偏多 ${ }^{[5]}$. Zhao 等人 ${ }^{[6]}$ 还指出, 春季白令海和鄂霍茨克海海冰面积减少(增 多)可使中国东部夏季降水量增加(减少). 周波涛等 人 $^{[7,8]}$ 基于观测资料分析和数值模拟研究, 提出春季 Hadley 环流强度与夏季长江流域降水之间存在显著 的正相关. 春季 Hadley 环流主要是通过影响印度洋南海区域海温进而影响长江流域夏季降水异常. 此 外, 一些研究还揭示, 北半球冬季 WA 遥相关型 [9]、 东亚冬季风[10,11]等的年际变化对夏季长江流域降水 异常也具有明显的影响.

以上研究从不同角度揭示了影响长江流域夏季 降水的北半球前期信号. 南半球作为季风发源地之

英文版见: Zhou B T. Linkage between winter sea surface temperature east of Australia and summer precipitation in the Yangtze River valley and a possible physical mechanism. Chinese Sci Bull, 2011, 56, doi: 10.1007/s11434-011-4497-9 
一和全球气候系统变化的关键区, 其大气环流异常 也必然会导致东亚夏季风异常并影响长江流域旱涝. 研究表明, 南极涛动作为南半球环流的主要模态, 它 的变动对东亚夏季风年际变化以及中国夏季降水变 化具有重要影响 ${ }^{[12 \sim 15]}$. 春季南极涛动增强时, 长江 流域夏季降水偏多, 反之, 春季南极涛动减弱时, 长 江流域夏季降水则偏少. 高辉等人 ${ }^{[16]}$ 的研究还表明, 5 月南极涛动加强会导致江淮出梅晚和梅雨期加长. 范可等人 ${ }^{[17]}$ 将南极涛动作为一个显著的预测因子, 建立了一个长江中下游夏季降水的物理统计预测模 型. 此外, 薛峰等人 ${ }^{[12,18]}$ 还从年际尺度分析了春季南 半球副热带高压(马斯克林高压和澳大利亚高压)的 变化对长江流域夏季降水的影响, 发现它们之间为 显著的正相关, 并且指出这种影响是通过改变西太 平洋副热带高压等来实现的.

可见，南半球大气环流异常对东亚夏季风环流 有显著影响, 而海温的变化又会对南半球大气环流 产生直接影响 ${ }^{[19,20]}$. 例如, 刘舸等人 ${ }^{[20]}$ 的研究揭示 澳大利亚东侧海温异常可以影响澳大利亚高压的变 化. 当夏季澳大利亚东侧海温升高(降低)时, 澳大利 亚高压东移或东扩(西缩). 由于南北半球的相互作用 主要是冬半球影响夏半球为主, 那么, 冬季澳大利亚 东侧海温的变化是否对夏季东亚大气环流特别是长 江流域降水存在影响? 如存在, 其中的物理过程又 是什么? 为此, 基于前人工作, 本文重点研究冬季澳 大利亚东侧海温与长江流域夏季降水的关系, 并探 讨其中联系的物理机制.

\section{1 资料}

所用资料包括: (1) 美国国家环境预报中心/大气 研究中心 (NCEP/NCAR) 的再分析资料 ${ }^{[21]}$, 水平分辨 率为 $2.5^{\circ} \times 2.5^{\circ}$; (2) 美国国家海洋和大气局 $(\mathrm{NOAA})$ 提供的海表温度 $(\mathrm{SST})^{[22]}$, 水平分辨率为 $2^{\circ} \times 2^{\circ}$; (3) 中国 160 站的月降水总量资料. 研究所用的时间长度 为 1951 2002 年. 文中冬季(DJF)指的是前一年 12 月 和当年的 1 与 2 月, 春季 $(\mathrm{MAM})$ 和夏季 $(\mathrm{JJA})$ 分别为当 年 3 5 月和 6 8 月, 季节划分均相对于北半球而言. 本文选取 6 8 月长江中下游的 17 站(南京、合肥、上 海、杭州、安庆、屯溪、九江、汉口、钟祥、岳阳、 宜昌、常德、宁波、倠县、贵溪、南昌、长沙)平均 降水量作为长江流域夏季降水指数(YRRI), 以此表 征长江流域夏季降水量的旱涝变化.

\section{2 澳大利亚东侧冬季海温与长江流域夏季 降水}

图 1(a)是长江流域夏季降水与冬季 SST 的相关 分布. 可见, 澳大利亚东侧海区为显著的正相关, 最 大相关系数超过 0.4 , 揭示冬季澳大利亚东侧 SST 异 常偏暖时, 夏季长江流域降水往往偏多. 反之, 冬季 澳大利亚东侧 SST 异常偏冷时, 夏季长江流域降水 往往偏少. 为衡量澳大利亚东侧海区 SST 的变化, 选 取图 1(a)中显著相关区域平均的 SST 作为海温指数 (EASST). 图 1(b)给出了冬季 EASST 与夏季 YRRI 的 时间变化曲线. 如图所示, 两者之间具有同位相变化 特征(相关系数为 0.40 , 超过 $99 \%$ 的信度). 从图 1(b) 还可以看到, 冬季 EASST 和夏季 YRRI 在研究时段 内都呈现线性增长的趋势。扣除线性趋势后, 冬季 EASST 和夏季 YRRI 之间的相关系数为 0.35 , 仍高于 95\%的信度. 因此, 冬季澳大利亚东侧 SST 与长江流 域夏季降水在年际时间尺度上存在显著联系. 本文 重点研究两者在年际时间尺度上的联系，所以在随 后的分析中均扣除了线性趋势.

为了阐述澳大利亚东侧冬季 SST 和长江流域夏

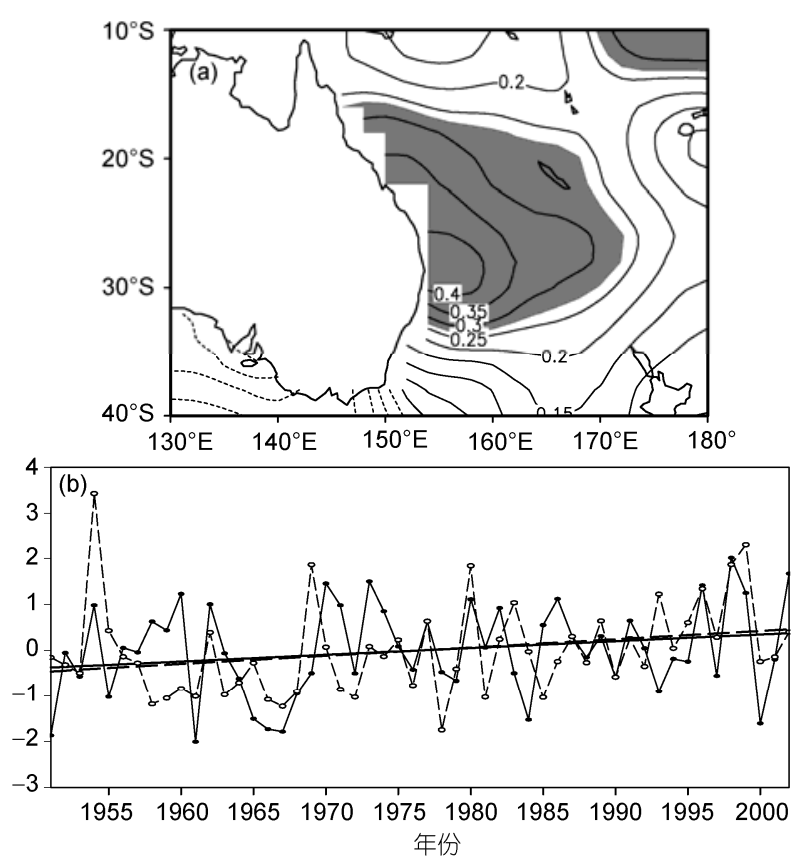

图 1 长江流域夏季降水指数(YRRI)与冬季 SST 的相关(a) 及夏季 YRRI(虚线)和冬季 EASST(实线)的标准化时间序列 以及各自的趋势(b)

阴影区表示通过 $95 \%$ 信度 
季降水正相关关系背后的大尺度环流背景, 分析了 夏季低层水平风场分别与冬季 EASST 和夏季 YRRI 的回归分布(图 2). 图 2(a)显示，与 YRRI 相关联的 $700 \mathrm{hPa}$ 水平风场的变化特征为: $30^{\circ} \mathrm{N}$ 以南的西太平 洋地区为异常的反气旋型环流, 东亚热带季风槽区 为东风异常, 梅雨锋区为西风异常, 指示夏季西太平 洋副热带高压偏南. 另外, 在我国东部沿岸盛行异常 的西南风, 有利于水汽从热带向中纬地区输送. 这种 分布特征与张庆云等人 ${ }^{[23]}$ 所得的结论相吻合. 他们 的研究指出, 西太平洋上 $30^{\circ} \mathrm{N}$ 以南出现异常反气旋 距平环流时，长江流域夏季降水偏多。与冬季 EASST 相联系的低层风场的变化(图 2(b))与图 2(a)揭 示的特征相类似. 即在西太平洋 $30^{\circ} \mathrm{N}$ 以南地区同样 存在异常的反气旋型环流, 而且我国东部沿岸盛行 异常的西南风气流. 这种分布型态说明, 当澳大利亚 东侧冬季 SST 异常升高(降低)时, 随后夏季 $30^{\circ} \mathrm{N}$ 以 南的西太平洋地区会出现异常的反气旋型(气旋型) 环流, 西太平洋副热带高压偏南(北). 这种环流背景
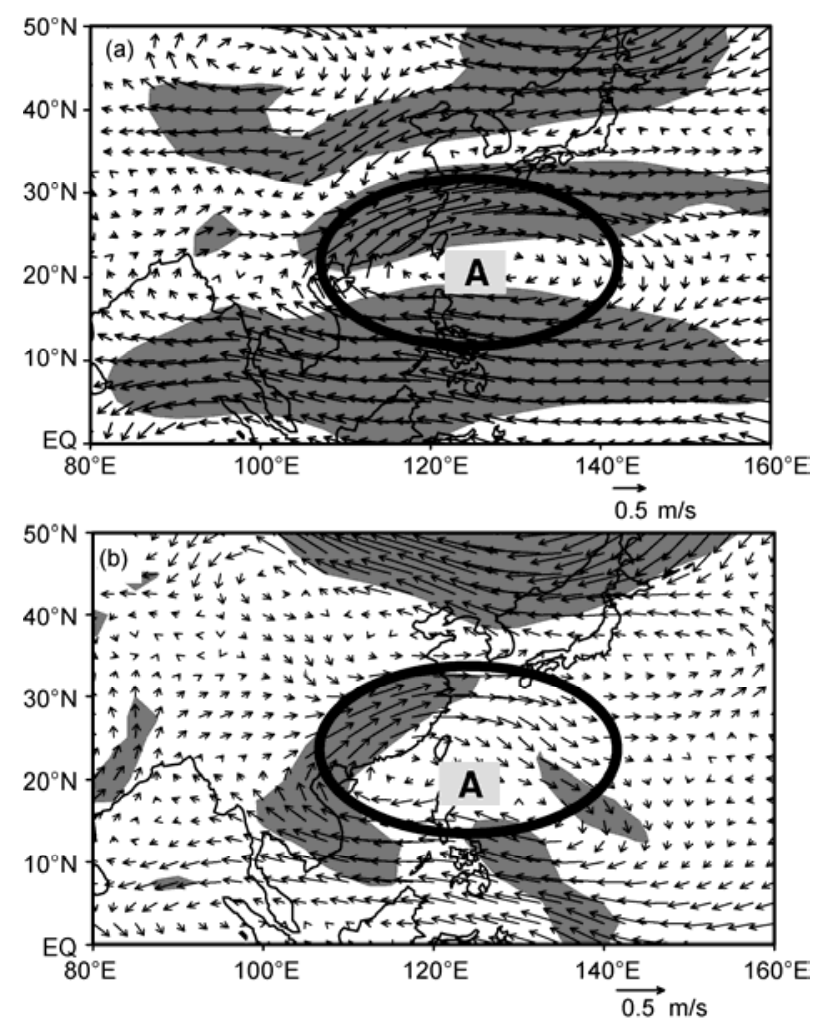

图 2 夏季 $700 \mathrm{hPa}$ 水平风场与同期 YRRI (a)和冬季 EASST (b) 的回归分布

阴影区表示通过 $95 \%$ 信度; A 代表反气旋环流系统
有(不)利于长江流域降水的发生, 长江流域夏季降水 因而增加(减少).

东亚西风急流的变化, 尤其是急流位置的变化 对长江流域夏季降水同样具有重要的影响. 当急流 位置偏南 (北)时, 长江流域降水偏多(偏少) $)^{[24,25]}$. 这点可从夏季 $200 \mathrm{hPa}$ 纬向风与 YRRI 的回归分布图 (图 3(a))上得到证实. 图 3(a)清楚地显示, 与长江流 域降水偏多相联系的高空大气环流特征表现为: $40^{\circ} \mathrm{N}$ 南北两侧分别为西风异常和东风异常, 昭示西 风急流位置偏南(西风急流中心的平均位置位于 $40^{\circ} \mathrm{N}$ ). 冬季 EASST 与夏季 $200 \mathrm{hPa}$ 纬向风的回归分 布(图 3(b))表现出与图 3(a)相一致的特点. 即, 当冬 季 EASST 偏高时, $40^{\circ} \mathrm{N}$ 以北区域为负值, 高空西风 减弱, $40^{\circ} \mathrm{N}$ 以南区域为正值, 高空西风加强. 因此, 东亚西风急流位置较常年偏南，与这种环流特征相 对应的正是我国长江流域降水偏多, 再次印证了冬 季澳大利亚东侧 SST 与夏季长江流域降水的正相关 变化关系.
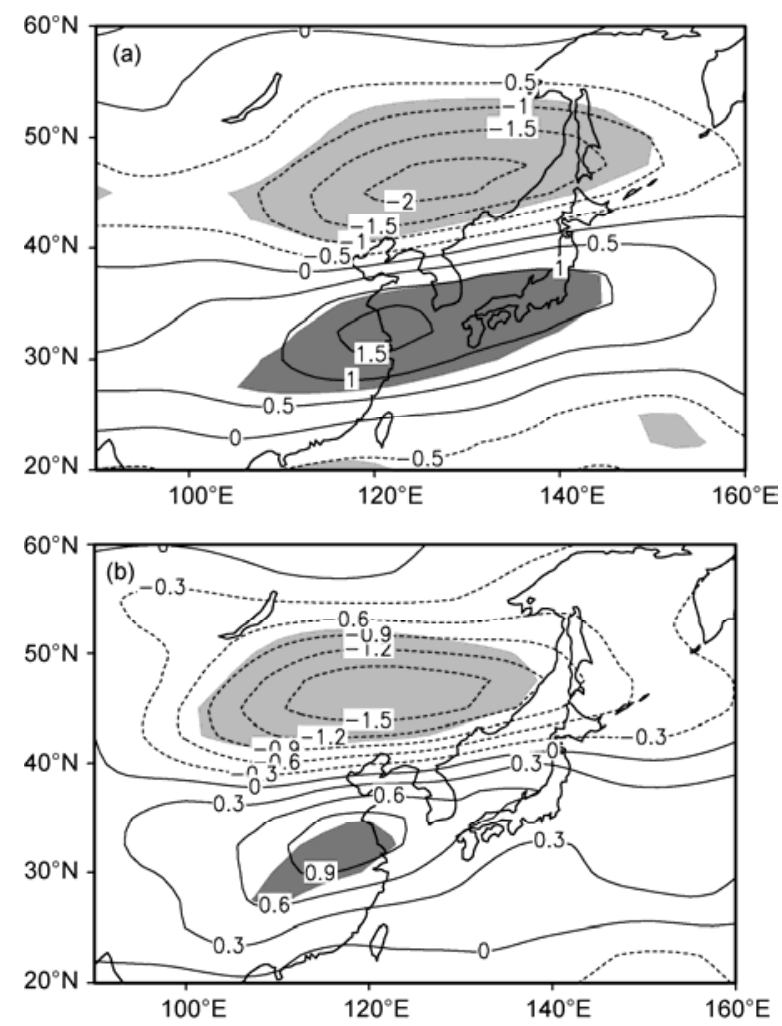

图 3 夏季 $200 \mathrm{hPa}$ 纬向风 $(\mathrm{m} / \mathrm{s})$ 与同期 YRRI (a) 和冬季 $\operatorname{EASST}(\mathbf{b})$ 的回归分布

阴影区表示通过 $95 \%$ 信度 


\section{3 可能的物理机制}

从以上分析可知, 澳大利亚东侧冬季 SST 的变 化可以影响后期夏季东亚大气环流系统, 从而导致 我国长江流域夏季降水出现显著的年际波动. 那么, 冬季澳大利亚东侧 SST 是通过何种途径影响夏季东 亚大气环流系统的? 其中具体的物理过程又是什么? 为回答这一问题, 分别计算了冬季 EASST 与同期以 及后期春季和夏季 SST 的相关分布, 结果如图 4 所示. 从该图上可以看到两个明显的特征.一个是澳大利 亚东侧海温信号自身的持续性. 在澳大利亚东侧海 域, 相关系数从冬季到夏季都为显著的正值, 而且是 逐渐减小的. 另一个是南印度洋海温的发展和东传. 冬季, EASST 与西南印度洋 SST 具有显著的正相关, 随后, 正相关区域逐渐向东移动并在夏季位于海洋 大陆上.
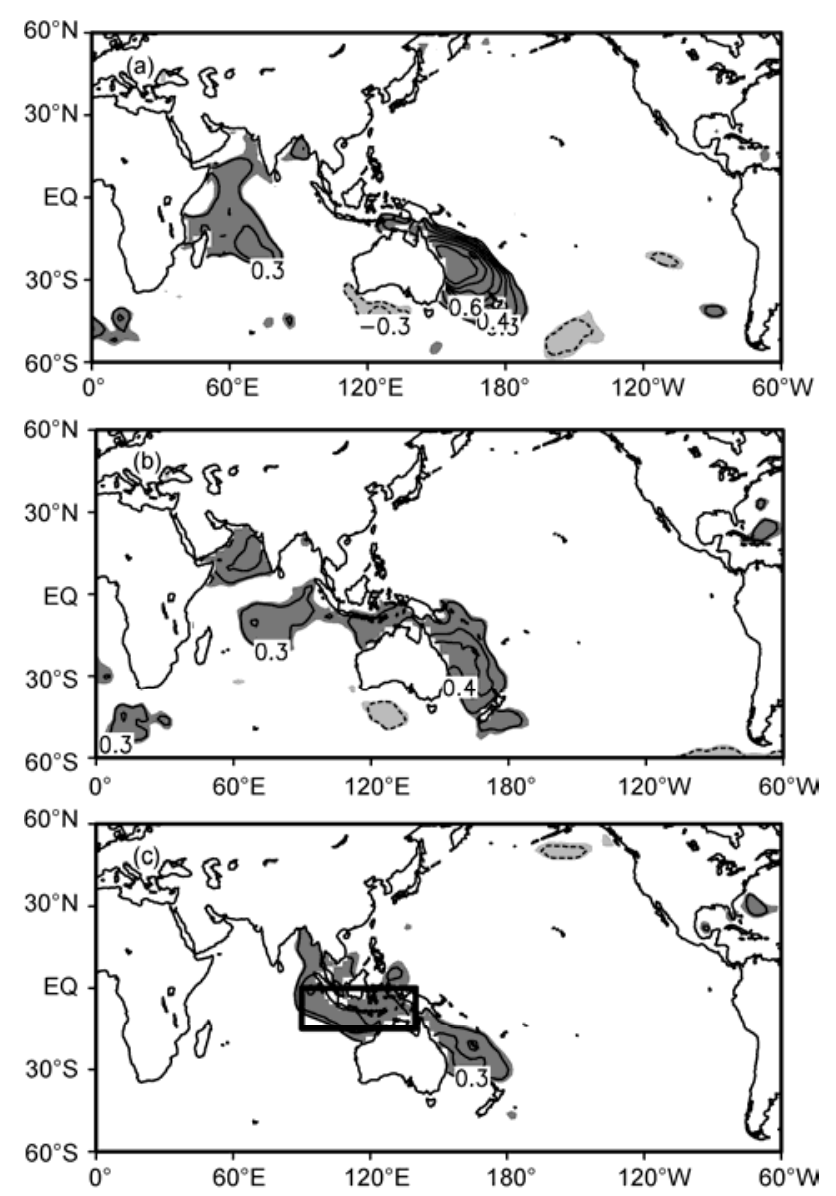

图 4 冬季 EASST 与冬季 $(a)$ 、春季(b)和夏季 (c) SST 相关的 空间分布

阴影区表示通过 $95 \%$ 信度
因此, 澳大利亚东侧 SST 变化可能通过如下两 种途径影响夏季大气环流和降水的变化. 当冬季澳 大利亚东侧 SST 出现异常时, 一方面由于海温自身 的记忆能力, 这种异常信号可以维持到夏季, 而夏季 澳大利亚东侧的局地 SST 异常可以激发南北半球遥 相关 ${ }^{[26]}$, 进而影响长江流域降水. 当夏季澳大利亚 东侧 SST 偏高(低)时, 该区域位势高度偏高(低), 这 种气压异常扰动通过 Rossby 波列传播到北半球副热 带地区, 致使西太平洋副热带高压偏强(偏弱)并偏南 偏西(偏北偏东), 结果造成长江中下游地区降水偏多 (少 $)^{[20,26]}$. 另一方面, 当冬季澳大利亚东侧 SST 偏暖 (冷)时, 同期西南印度洋 SST 也异常偏暖(冷). 该异 常信号随后逐渐发展和向东移动, 并造成夏季海洋 大陆区域 SST 异常, 最终影响夏季大气环流的变化. 夏季海洋大陆 SST 异常对同期大气环流的影响可由 $\left(90^{\circ} \sim 140^{\circ} \mathrm{E}, 0^{\circ} \sim 15^{\circ} \mathrm{S}\right)$ (如图 4(c)中矩形框所示) 区域平 均的 SST 与散度场的相关分布(图 5)得到佐证. 高层 $150 \mathrm{hPa}$ (图 5(a)), 海洋大陆基本上为显著的正相关, 而在西太平洋地区为显著的负相关. 低层 $1000 \mathrm{hPa}$ 的相关分布则相反，在海洋大陆为显著的负相关，在 西太平洋地区为显著的正相关(图 5(b)). 这种相关分
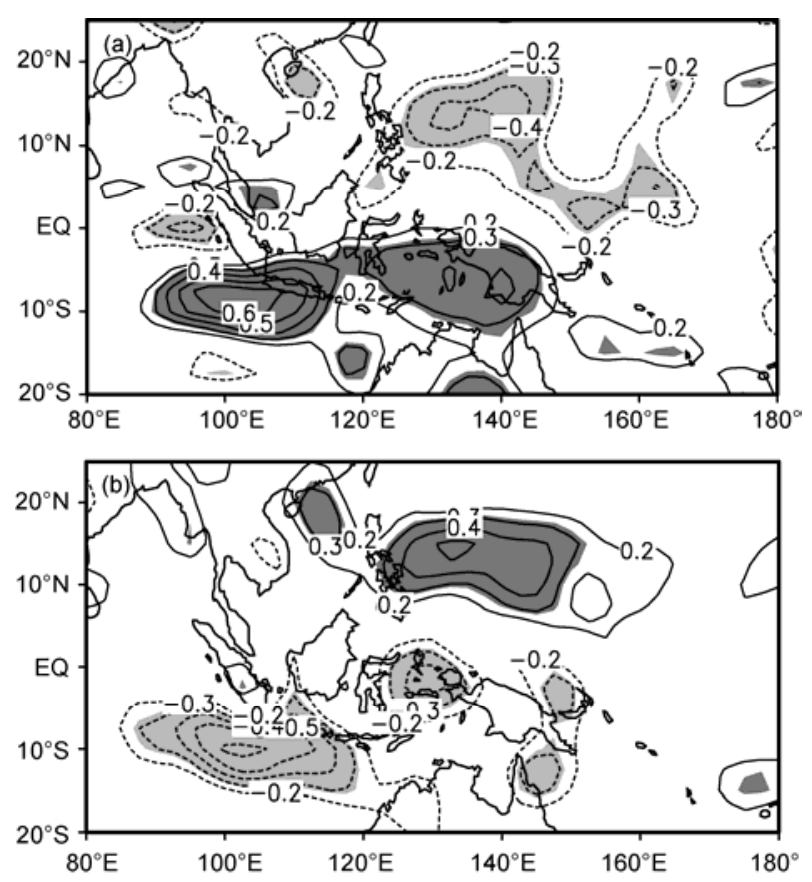

图 5 夏季 $\left(90^{\circ} \sim 140^{\circ} \mathrm{E}, 15^{\circ} \mathrm{S} \sim 0^{\circ}\right)$ 平均 $\mathrm{SST}$ 与 $150 \mathrm{hPa}(\mathrm{a})$ 和 $1000 \mathrm{hPa}(\mathrm{b})$ 散度场相关的空间分布

阴影区表示通过 $95 \%$ 信度; 图中仅给出大(小)于 $0.2(-0.2)$ 的 相关系数值 
布型态表明, 当海洋大陆夏季 SST 偏暖时, 该地区高 层为异常辐散, 低层为异常辐合, 对流活动旺盛; 而 在西太平洋地区特别是菲律宾以东洋面, 高层为异 常辐合, 低层为异常辐散, 对流活动减弱, 减弱的对 流活动可以通过 $\mathrm{PJ}$ 遥相关波列影响夏季东亚大气环 流和长江流域降水 ${ }^{[27,28]}$.

为进一步探讨澳大利亚东侧 SST 与西南印度洋 SST 的关联, 选取扣除线性趋势后的标准化冬季 EASST 值大于(小于) $1(-1)$ 的年份作为正(负)异常组 合进行合成分析. 这样选取的正负 EASST 异常组合 分别有 11 和 8 年. 图 6 是强弱 EASST 年冬季 $200 \mathrm{hPa}$ 纬向风的合成差异. 可见, 在澳大利亚东侧和南非西南印度洋之间存在一个明显的遥相关分布型(如 图 6 中粗虚线所示), 这个遥相关型将两个区域的大 气环流变化联系在一起. 当冬季澳大利亚东侧 SST 偏高时, 该区域高层出现反气旋型环流异常, 而在 南非-西南印度洋区域则出现气旋型环流异常, 反之 亦然.

相应于高空大气环流的变化, 西南印度洋区域 的低层大气环流也将作出调整. 从图 7(a)可以看到, 在马达加斯加东侧的西南印度洋出现气旋型环流异 常, 其东北侧为反气旋型环流异常，两者之间盛行异 常的西北气流. 研究表明, 由风驱动的海洋动力过程 (海水上翻/下沉和温跃层变化)是导致西南印度洋 SST 变化的主要原因 ${ }^{[29 ~ 31]}$. 因此, 图 7(a)揭示的异常 表层风将会对局地 SST 的变化产生重要影响. 位于 西南印度洋上的气旋型环流北侧的风旋度可驱动向 下的 Ekman 抽吸, 结果使海水潜沉. 同时, 近赤道地 区的东风异常可以激发下沉的海洋 Rossby 波并造成 温跃层加深 ${ }^{[30,32]}$. 这些均有利于西南印度洋 SST 增 暖. 因此, 相应于图 7(a)中的异常表层风分布, 西南 印度洋冬季会出现正的 SST 异常.

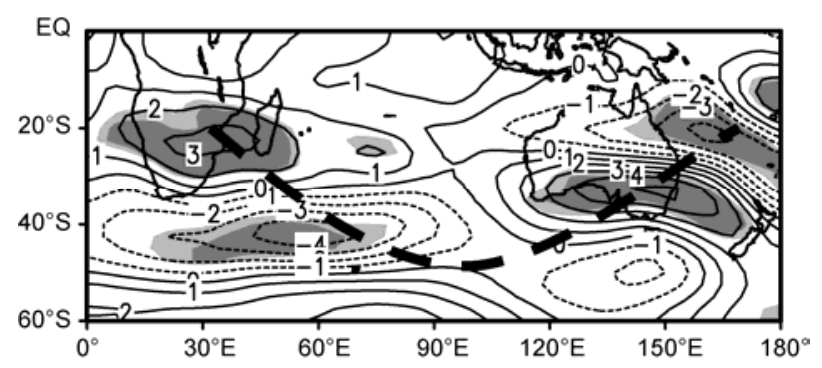

图 6 强弱 $\mathrm{EASST}$ 年冬季 $200 \mathrm{hPa}$ 纬向风 $(\mathrm{m} / \mathrm{s})$ 的合成差值 深(浅)阴影区表示通过 $95 \%$ (90\%)的信度
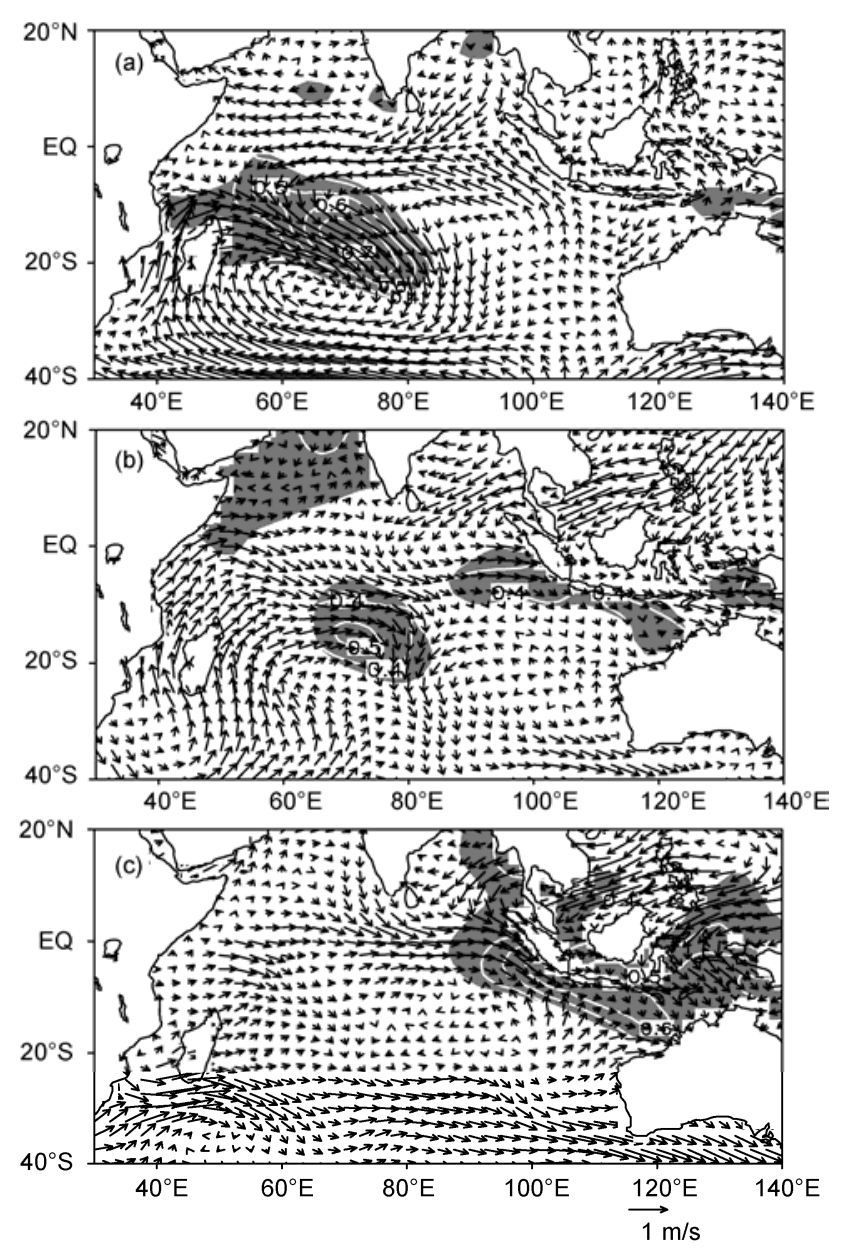

图 7 强弱 EASST 年表层风和 $\operatorname{SST}\left(\right.$ 等直线, ${ }^{\circ} \mathrm{C}$ )的合成差值 (a) 冬季; (b) 春季; (c) 夏季. 阴影区表示 SST 差异通过 95\%的信 度. 为清晰起见, 图中仅给出通过显著性检验的 SST 差值

西南印度洋 SST 增暖后又会影响春季表层风的 变化. 春季(图 7(b)), 在海温变暖区域将出现异常的 气旋型环流，在其东北侧则出现异常的反气旋型环 流. 表层风的这种异常分布是大气环流对不对称加 热响应的一种体现 ${ }^{[33]}$. 另一方面, 表层风的异常反 过来又可影响到局地 SST 的变化. 与异常气旋型环 流相联系的 Ekman 上升流抑制下沉的海洋 Rossby 波, 从而减弱西南印度洋 SST 增暖, 呈现负反馈关 系 ${ }^{[34,35]}$. 在苏门答腊和爪哇岛一带为异常的西北气 流.气候意义下，该区域盛行东南风，所以西北风异 常意味着该区域东南风减弱，减弱的东南风可以通 过蒸发减少和海流下沉造成海岸带 SST 升高 ${ }^{[36,37]}$.

夏季，海岸带 SST 异常在风-蒸发-SST 反馈机制 (WES feedback $)^{[38,39]}$ 下进一步发展。也就是, 春季 
SST 异常的南北差异(赤道以南增温幅度大于赤道以 北的增温幅度)可在表层强迫出向南的气压梯度力并 产生异常北风. 在科氏力的作用下, 赤道以南(北)的 北风向东(西)偏转形成西北风(东北风)(图 7(c)). 赤道 以南的西北风异常通过减少蒸发和引起海水下沉促 使海洋大陆附近 SST 进一步增暖.

\section{4 结论}

本文研究了冬季澳大利亚东侧 SST 与我国长江 流域夏季降水的关系. 结果表明, 澳大利亚东侧冬季 SST 与长江流域夏季降水之间存在显著的正相关. 与澳大利亚东侧冬季 SST 相关联的东亚大气环流条 件为这一关系的存在提供了背景场. 当前期冬季澳 大利亚东侧 SST 偏暖时, 夏季西太平洋副热带高压 和东亚西风急流位置偏南, 我国东部沿岸低层盛行 西南风异常. 这种环流背景有利于长江流域降水的 发生, 我国长江流域夏季降水因而偏多. 冬季澳大利 亚东侧 SST 偏冷时的情况则相反, 不利于长江流域 降水的发生，长江流域夏季降水因而减少.
本文还进一步探讨了前期冬季澳大利亚东侧 SST 与后期夏季东亚大气环流联系的可能物理机制. 研究揭示, 澳大利亚东侧冬季 SST 异常可能通过其 自身的持续性和南印度洋海温的调制作用影响东亚 夏季大气环流. 当冬季澳大利亚东侧 SST 出现正异 常时, 由于 SST 本身的记忆能力, 这种异常信号一直 维持到夏季, 并通过南北半球遥相关影响到西太平 洋副热带高压强度和位置的变化, 进而导致长江流 域夏季降水偏多. 同时, 冬季澳大利亚东侧 SST 增暖 时，西南印度洋同期 SST 也易于增暖. 两区域的海温 变化可通过大气遥相关波列联系在一起. 随后, 在海 气相互作用下, 西南印度洋 SST 异常增暖信号逐渐 向东发展, 并造成夏季海洋大陆附近 SST 升高, 而海 洋大陆附近 SST 的升高可以通过影响对流活动进而 影响东亚夏季大气环流和降水. 当然, 这只是一个初 步解释. 海气相互作用是一个比较复杂的问题, 冬季 澳大利亚东侧 SST 还可能通过其他途径影响后期大 气环流的变化. 这有待于今后作更多的分析和采用 先进的气候模式作深人的研究.

\section{参考文献}

1 龚道溢, 朱锦红, 王绍武. 长江流域夏季降水与前期北极涛动的显著相关. 科学通报, 2002, 47: 546-549

2 Gong D Y, Ho C H. Arctic Oscillation signals in the East Asian summer monsoon. J Geophys Res, 2003, 108: 4066, doi: 10.1029/2002JD002193

3 王会军. 关于我国几个大水年大气环流特征的几点思考. 应用气象学报, 2000, 11: 79-86

4 Wang H J, Matsuno T, Kurihara Y. Ensemble hindcast experiments for the flood period over china in 1998 by use of the CCSR/NIES atmospheric general circulation model. J Meteorol Soc Jpn, 2000, 78: 357-365

5 Zhao P, Zhou Z J, Liu J P. Variability of Tibetan spring snow and its associations with the hemispheric extratropical circulation and East Asian summer monsoon rainfall: A observational investigation. J Clim, 2007, 20: 3942-3955

6 Zhao P, Zhang X D, Zhou X J, et al. Sea-ice extent anomaly in the North Pacific and its impact on the East Asian summer monsoon rainfall. J Clim, 2004, 17: 3434-3447

7 Zhou B T, Wang H J. Relationship between the boreal spring Hadley circulation and the summer precipitation in the Yangtze River valley. J Geophys Res, 2006, 111: D16109, doi: 10.1029/2005JD007006

8 周波涛, 崔绚. 春季 Hadley 环流与长江流域夏季降水关系的数值模拟. 气候与环境研究, 2008, 13: 182-188

9 徐海明, 何金海, 管兆勇, 等. 北半球 WA 遥相关型影响东亚初夏季风的可能途径. 南京气象学院学报, 2000, 23: 361-369

10 孙淑清, 孙柏民. 东亚冬季风环流异常与中国江淮流域夏季早涝天气的关系. 气象学报, 1995, 53: 438-450

11 Chen W, Graf H F, Huang R H. The interannual variability of East Asian winter monsoon and its relation to the summer monsoon. Adv Atmos Sci, 2000, 17: 48-60

12 Xue F, Wang H J, He J H. Interannual variability of Mascarene high and Australian high and their influences on East Asian summer monsoon. J Meteorol Soc Jpn, 2004, 82: 1173-1186

13 Wang H J, Fan K. Central-north China precipitation as reconstructed from the Qing dynasty: Signal of the Antarctic Atmospheric Oscillation. Geophys Res Lett, 2005, 32: L24705, doi: 10.1029/2005GL024562

14 范可. 南半球环流异常与长江中下游夏季早涝的关系. 地球物理学报, 2006, 49: 672-679

15 Sun J Q, Wang H J, Yuan W. A possible mechanism for the co-variability of the boreal spring Antarctic Oscillation and the Yangtze River valley summer rainfall. Int J Climatol, 2009, 29: 1276-1284

16 高辉, 薛峰, 王会军. 南极涛动年际变化对江淮梅雨的影响及预测意义. 科学通报, 2003, 48(增刊 II ): 87-92 
17 范可, 王会军, Choi Y J. 一个长江中下游夏季降水的物理统计预测模型. 科学通报, 2007, 52: 2900-2905

18 薛峰, 王会军, 何金海. 马斯克林高压和澳大利亚高压的年际变化及其对东亚夏季降水的影响. 科学通报, 2003, 48: 287-291

19 周波涛, 崔绚. 澳大利亚东侧海温: 西北太平洋热带气旋生成频数的预测信号? 科学通报, 2010, 55: 3053-3059

20 刘舸, 张庆云, 孙淑清. 澳大利亚东侧环流及海温异常与长江中下游夏季旱涝的关系. 大气科学, 2008, 32: 231-241

21 Kalnay E, Kanamistu M, Kistler R, et al. NCEP/NCAR 40-year reanalysis project. Bull Am Meteorol Soc, 1996, 77: 437-471

22 Smith T M, Reynolds R W. Improved extended reconstruction of SST (1854-1997). J Clim, 2004, 17: 2466-2477

23 张庆云, 陶诗言, 陈烈庭. 东亚夏季风指数的年际变化与东亚大气环流. 气象学报, 2003, 61: 559-568

24 Liang X Z, Wang W C. Association between China monsoon rainfall and tropospheric jets. Q J R Meteorol Soc, 1998, 124: 2597-2623

25 Lau K M, Kim K M, Yang S. Dynamical and boundary forcing characteristics of regional components of the Asian summer monsoon. J Clim, 2000, 13: 2461-2482

26 Liu G, Ji L R, Sun S Q, et al. An inter-hemispheric teleconnection and a possible mechanism for its formation. Adv Atmos Sci, 2010, 27: $629-638$

27 Nitta T. Convective activities in the tropical western Pacific and their impact on Northern Hemisphere summer circulation. J Meteorol Soc Jpn, 1987, 65: 373-390

28 Huang R H, Sun F Y. Impact of the tropical western Pacific on the East Asian summer monsoon. J Meteorol Soc Jpn, 1992, 70: 243-256

29 Klein S A, Soden B, Lau N C. Remote sea surface temperature variations during ENSO: Evidence for a tropical atmospheric bridge. J Clim, 1999, 12: 917-932

30 Xie S P, Annanalai H, Schott F A, et al. Structure and mechanisms of South Indian Ocean climate variability. J Clim, 2002, 15: 864-878

31 Yu L, Jin X Z, Weller R A. Annual, seasonal, and interannual variability of air-sea heat fluxes in the Indian Ocean. J Clim, 2007, 20: 3190-3209

32 Huang B, Kinter III J L. Interannual variability in the tropical Indian Ocean. J Geophys Res, 2002, 107: 3199 , doi: 10.1029/2001JC001278

33 Wu R G, Kirtman B P, Krishnamurthy V. An asymmetric mode of tropical Indian Ocean rainfall variability in boreal spring. J Geophys Res, 2008, 113: D05104, doi: 10.1029/2007JD009316

34 Philander S G H, Yamagata T, Pacanowski R C. Unstable air-sea interactions in the Tropics. J Atmos Sci, 1984, 41: 604-613

35 Hirst A C. Unstable and damped equatorial modes in simple coupled ocean-atmosphere models. J Atmos Sci, 1986, 43: 606-630

36 Saji N H, Goswami B N, Vinayachandran P N, et al. A dipole mode in the tropical Indian Ocean. Nature, 1999, 401: 360-363

37 Murtugudde R, McCreary J P, Busalacchi A J. Oceanic processes associated with anomalous events in the Indian Ocean with relevance to 1997-1998. J Geophys Res, 2000, 105: 3295-3306

38 Xie S P, Philander S G H. A coupled ocean-atmosphere model of relevance to the ITCZ in the eastern Pacific. Tellus, 1994, 46A: 340-350

39 Chang P, Ji L, Li H. A decadal climate variation in the tropical Atlantic Ocean from thermodynamics air-sea interactions. Nature, 1997, 385: $516-518$ 